\title{
LIMING IN AGRICULTURAL PRODUCTION MODELS WITH AND WITHOUT THE ADOPTION OF CROP-LIVESTOCK INTEGRATION
}

\author{
Francisco Carlos Mainardes da Silva ${ }^{(1)^{*}}$, Luís Guilherme Sachs ${ }^{(1)}$, Inês Cristina Batista \\ Fonseca $^{(2)}$ and João Tavares Filho ${ }^{(2)}$
}

(1) Universidade Estadual do Norte do Paraná, Campus Luiz Meneghel, Centro de Ciências Agrárias, Bandeirantes, Paraná, Brasil.
(2) Universidade Estadual de Londrina, Departamento de Agronomia, Londrina, Paraná, Brasil.
* Corresponding author.
E-mail: mainardesilva@ffalm.br

\begin{abstract}
Perennial forage crops used in crop-livestock integration (CLI) are able to accumulate large amounts of straw on the soil surface in no-tillage system (NTS). In addition, they can potentially produce large amounts of soluble organic compounds that help improving the efficiency of liming in the subsurface, which favors root growth, thus reducing the risks of loss in yield during dry spells and the harmful effects of "overliming". The aim of this study was to test the effects of liming on two models of agricultural production, with and without crop-livestock integration, for 2 years. Thus, an experiment was conducted in a Latossolo Vermelho (Oxisol) with a very clayey texture located in an agricultural area under the NTS in Bandeirantes, PR, Brazil. Liming was performed to increase base saturation (V) to 65,75 , and $90 \%$ while one plot per block was maintained without the application of lime (control). A randomized block experimental design was adopted arranged in split-plots and four plots/block, with four replications. The soil properties evaluated were: $\mathrm{pH}$ in $\mathrm{CaCl}_{2}$, soil organic matter (SOM), $\mathrm{Ca}, \mathrm{Mg}, \mathrm{K}, \mathrm{Al}$, and $\mathrm{P}$. The effects of liming were observed to a greater depth and for a long period through mobilization of ions in the soil, leading to a reduction in SOM and $\mathrm{Al}$ concentration and an increase in $\mathrm{pH}$ and the levels of Ca and Mg. In the first crop year, adoption of CLI led to an increase in the levels of $\mathrm{K}$ and $\mathrm{Mg}$ and a reduction in the levels of SOM; however, in the second crop year, the rate of decline of SOM decreased compared to the decline observed in the first crop year, and the level of $K$ increased, whereas that of $P$ decreased. The extent of the effects of liming in terms of depth and improvement in the root environment from the treatments were observed only partially from the changes observed in the chemical properties studied.
\end{abstract}

Keywords: Brachiaria ruziziensis, no-tillage system, ion mobility. 


\title{
RESUMO: CALAGEM EM MODELOS DE PRODUÇÃO AGRÍCOLA COM E SEM A ADOÇÃO DA INTEGRAÇÃO LAVOURA-PECUÁRIA
}

\begin{abstract}
As forrageiras perenes utilizadas na integração lavoura-pecuária (ILP) têm capacidade de acumular grande quantidade de palhada na superfície do solo no sistema de plantio direto (SPD). Além disso, potencialmente podem produzir grandes quantidades de compostos orgânicos hidrossolúveis que ajudam a melhorar a eficiência do calcário na subsuperfície, o que favorece o crescimento radicular e, assim, diminui os riscos de perdas de rendimentos nos veranicos e os eventuais efeitos nocivos da "supercalagem". Objetivou-se testar por dois anos os efeitos da calagem em dois modelos de produção agrícola, com e sem a estratégia da integração lavoura-pecuária. Para tanto, foi conduzido um experimento em um Latossolo Vermelho, textura muito argilosa, localizado em área agrícola manejada com SPD, no município de Bandeirantes, PR. A calagem foi realizada para elevar a saturação por bases (V) a 65, 75 e $90 \%$, sendo mantida uma parcela por bloco sem calagem (controle). O delineamento experimental adotado foi o de parcelas subdivididas em blocos casualizados com quatro repetições e quatro parcelas /bloco, sendo avaliados: $\mathrm{pH}\left(\mathrm{CaCl} \mathrm{l}_{2}\right), \mathrm{matéria}$ orgânica do solo (MOS), Ca, $\mathrm{Mg}, K$, Al e P. Os efeitos do calcário foram estendidos em profundidade e no longo do tempo por meio dos mecanismos de mobilização de íns no solo, promovendo redução da MOS e teor de Al, bem como aumento no pH e nos teores de Ca e Mg. No primeiro ano agrícola, a adoção da ILP promoveu aumento nos teores de Ke Mg e redução nos teores de MOS, mas no segundo ano agrícola diminuiu o decréscimo de MOS, aumentou o teor de $K$ e reduziu o teor de $P$. A extensão dos efeitos da calagem em profundidade e melhoria no ambiente radicular, em razão dos tratamentos, somente foram observadas parcialmente nas mudanças verificadas nos atributos químicos estudados.
\end{abstract}

Palavras-chave: Brachiaria ruziziensis, sistema plantio direto, mobilidade de íns.

\section{INTRODUCTION}

In the north region of Paraná, Brazil, lack of groundwater prevents securing the full benefits of permanently maintaining straw on the soil surface in no-tillage system (NTS), which causes loss of crop yield, soil depletion, and weed infestation. To overcome this problem, plant species managed in crop rotation models would need to generate 1.5 times or more dry matter than the current average, or close to $8 \mathrm{Mg} / \mathrm{ha} / \mathrm{yr}$ of dry mass, to provide soil coverage close to $100 \%$ (Franchini et al., 2009).

Intercropping summer grain crops with forage crops can provide increased forage availability during a dry season, with enough nutritive value for the nutritional maintenance of herds (Klutchcouski et al., 2004; Borghi and Crusciol, 2007). It may even promote weight gain and straw production for the NTS without the need for sowing cover crops in the winter or spring. Thus, at the time of soybean cultivation in areas in which the previous crop was a winter crop maize or a summer crop intercropped with Brachiaria ruziziensis or $B$. brizantha, the amount of straw can range from $8 \mathrm{Mg} / \mathrm{ha}$ (Franchini et al., 2009) up to $20 \mathrm{Mg} / \mathrm{ha}$ (Crusciol et al., 2009). This is of utmost importance for the sustainability of NTS in these regions, as emphasized by Borghi (2004), especially considering that the perennial fodder crop does not significantly interfere with maize yield (Denardin et al., 2008).

In addition to intercropping grain crops with forage crops, an environment that is conducive to root growth, and thus provides plants with water stored in the subsurface, should be considered to address the problem of low production of surface straw and crops in regions with dry winters. This can be achieved through soil amendment at a greater depth (Quaggio, 2000; Raij, 2011), but because agricultural liming material is not incorporated and has low efficiency in the correction of subsurface acidity, it tends to produce very slow effects at depth. For that reason, over time, the effects of lime are concentrated in the first few centimeters of the soil surface, leading to "overliming" in this layer and resulting in nutritional deficiency of micronutrients and clay dispersion. Below this layer, toxic levels of $\mathrm{Al}$ and $\mathrm{Mn}$, low $\mathrm{pH}$, and low concentrations of $\mathrm{Ca}$ and $\mathrm{Mg}$ result. However, liming efficiency could be improved with soluble organic compounds released by plant residues (Miyazawa et al., 2000; Franchini et al., 2001), which can insolubilize $\mathrm{Al}$, raise the $\mathrm{pH}$ value, and transport $\mathrm{Ca}$ and $\mathrm{Mg}$ deeper into the soil (Ciotta et al., 2004).

Thus, in order to extend the effects of liming at a depth that could provide a better environment for root growth and minimize the risks associated with the occurrence of droughts, while also reducing the effects of "overliming" over time, this study tested two models of agricultural production associated with lime application.

\section{MATERIAL AND METHODS}

The experiment was conducted in 2 crop years (the 2011/12 and 2012/13 seasons) in an area 
managed under a no-tillage system located in the municipality of Bandeirantes, PR, Brazil, at the Luiz Meneghel Campus of the Universidade Estadual do Norte do Paraná. Altitude in this area is $440 \mathrm{~m}$, and the soil is classified as a Latossolo Vermelho Eutroférrico (Oxisol) (Santos et al., 2013). Average annual rainfall in the municipality is $1,443 \mathrm{~mm}$, and the climate is defined as humid subtropical (Cfa) with hot summers, based on the Köppen classification (Alvarez et al. (2013).

The experimental plots were first demarcated and, on October 22, 2011, a maize crop was planted using the Pioneer cultivar $30 \mathrm{~F} 35 \mathrm{H}$ at a density of 3.4 seeds $/ \mathrm{m}$ and a spacing of $0.45 \mathrm{~m}$ between rows (2011/2012 season).

After 20 days, each plot was split into two plots and, in one of them, Brachiaria ruziziensis was sown in rows at a density of $10 \mathrm{~kg} / \mathrm{ha}$ of seed and a spacing of $0.45 \mathrm{~m}$ between rows, establishing a maize-Brachiaria intercrop.

After the maize harvest on March 5, 2012, soils in all split-plots were sampled at the $0.00-0.20 \mathrm{~m}$ layer and analyzed for the purpose of calculating the rates of lime application to be used in treatments. In mid-March 2012, the split-plots received an application of calcitic lime with a total neutralizing power of $86 \%$. To increase the base saturation (V) to $65 \%$, lime was applied at rates from 0.21 to $0.43 \mathrm{Mg} / \mathrm{ha}$; for a $\mathrm{V}$ of $75 \%$, rates ranged from 1.25 to $2.49 \mathrm{Mg} / \mathrm{ha}$; and for $90 \%$, rates ranged from 3.7 to $4.2 \mathrm{Mg} / \mathrm{ha}$. One plot/block was maintained without the application of lime (control).

On September 11, 2012, Brachiaria was desiccated with glyphosate herbicide at a rate of $3 \mathrm{~L} / \mathrm{ha}$, and one week before sowing, which occurred on November 7 , 2012, soil sampling was carried out in each split-plot. In this sampling, five disturbed soil samples were collected at the 0.00-0.05, 0.05-0.10, and 0.10-0.20 m layers and the following analyses were made: $\mathrm{pH}$ in $\mathrm{CaCl}_{2}, \mathrm{SOM}, \mathrm{Ca}, \mathrm{Mg}, \mathrm{K}, \mathrm{Al}$, and $\mathrm{P}$, following the methods described by Claessen et al. (1997).

Harvest (2012/13), in turn, began on November 7,2012 . A soybean crop was sown in each plot using the cultivar BMX Potência RR at a density of 17 seeds $/ \mathrm{m}$, with a spacing of $0.45 \mathrm{~m}$ between rows. After 20 days, Brachiaria was sown between the soybean rows at a density of $10 \mathrm{~kg}$ of seed/ha in the split-plots that had previously received the maize/ Brachiaria intercrop.

After the application of lime, this study tested two models of agricultural production: one with agricultural fallow in the first year after growing maize, followed by a soybean crop in the second year, again followed by fallow; in contrast with a crop-livestock integration (CLI) strategy, which involved B. ruziziensis, a remnant of intercropping with maize, in the first year, followed by soybean intercropped with a new crop of B. ruziziensis in the second crop year, with this forage remaining after the soybean harvest until the beginning of the new season.

In mid-September 2013, Brachiaria was again desiccated and, on October 13, 2013, new soil sampling began in all split-plots in the same manner as the sampling described above.

A randomized block experimental design was adopted arranged in split-plots and four plots/ block, with four replications. To evaluate the effect of liming and cultivation systems, the Pearson correlation analysis and linear regression were carried out. The significance of the correlation coefficient $(r)$ and coefficient of determination $\left(r^{2}\right)$ were analyzed using a $t$-test $(\mathrm{p} \leq 0.05)$. To determine the effects of these variables as a function of time, a $t$-test $(\mathrm{p} \leq 0.05)$ for paired samples was performed for each layer and for the cultivation model. A $t$-test $(p \leq 0.05)$ for non-paired samples was also conducted for each layer, assuming equal or different variances, according to prior analysis $(\mathrm{p} \leq 0.05)$.

\section{RESULTS AND DISCUSSION}

\section{Soil $\mathrm{pH}\left(\mathrm{CaCl}_{2}\right)$}

At the end of the first crop year, i.e., 234 days after liming (DAL), increasing rates of lime applied at a depth of 0.00-0.05 m led to an increase in soil $\mathrm{pH}$ (Table 1), as would be expected by the close correlation between $\mathrm{pH}$ and $\mathrm{V}$ (Motta and Melo, 2009; Lepsch, 2011).

In the 0.05-0.10 m soil depth, effects of the liming rates were only found in the plots without Brachiaria (Table 1), confirming the effect of lime in increasing the $\mathrm{pH}$ extended to a depth of $0.10 \mathrm{~m}$, with the effect amplified according to the rate of lime used on the surface. Furthermore, this finding indicated low molecular weight organic acids (LMWOAs) released during the initial decomposition of Brachiaria plant residues acted as organic binders with $\mathrm{Ca}$ and, or, $\mathrm{Mg}$ at 0.00-0.05 $\mathrm{m}$, acquiring a neutral or negative charge $\left(\mathrm{CaL}^{0}\right.$ or $\mathrm{CaL}$, or $\mathrm{MgL}^{0}$ or $\mathrm{MgL}$, where $\mathrm{L}=$ organic binder), as stated by Miyazawa et al. (2000). As this soil possibly had an increase in negative charges coinciding with the increase in $\mathrm{pH}$ in the $0.00-0.05 \mathrm{~m}$ soil layer, retention of these molecules was low in this layer, favoring the leaching of the cations in the form of organic compounds. Thus, in the 0.05-0.10 m layer, the intake of these multivalent cations may have been favored in the plots that received low rates of lime application since, at higher rates, the increase in $\mathrm{pH}$-dependent negative charges would have posed an obstacle to this process. Thus, once the exchange of these cations (associated with organic binders) with the hydrogen of the soil solution began, there 
Table 1. Pearson correlation coefficients among soil attributes and model of agricultural production at the 0.00-0.05, 0.05-0.10, and 0.10-0.20 m layers in a Latossolo Vermelho Eutroférrico (Oxisol)

\begin{tabular}{|c|c|c|c|c|}
\hline \multirow{3}{*}{$\operatorname{Variable}^{(1)} /$ layer } & \multicolumn{4}{|c|}{ Model of agricultural production } \\
\hline & \multicolumn{2}{|c|}{ Without Brachiaria } & \multicolumn{2}{|c|}{ With Brachiaria } \\
\hline & V\% 234 DAL & V\% 582 DAL & V\% 234 DAL & V\% 582 DAL \\
\hline $\mathrm{pH}\left(\mathrm{CaCl}_{2}\right)(0.00-0.05 \mathrm{~m})$ & 0.73 & 0.88 & 0.68 & 0.83 \\
\hline $\mathrm{pH}\left(\mathrm{CaCl}_{2}\right)(0.05-0.10 \mathrm{~m})$ & 0.55 & 0.74 & 0.38 & 0.82 \\
\hline $\mathrm{pH}\left(\mathrm{CaCl}_{2}\right)(0.10-0.20 \mathrm{~m})$ & 0.28 & 0.63 & 0.31 & 0.43 \\
\hline $\operatorname{SOM}\left(\mathrm{g} \mathrm{kg}^{-1}\right)(0.00-0.05 \mathrm{~m})$ & 0.22 & 0.19 & 0.07 & 0.47 \\
\hline $\operatorname{SOM}\left(\mathrm{g} \mathrm{kg}^{-1}\right)(0.05-0.10 \mathrm{~m})$ & 0.30 & 0.35 & -0.18 & 0.77 \\
\hline $\mathrm{SOM}\left(\mathrm{g} \mathrm{kg}^{-1}\right)(0.10-0.20 \mathrm{~m})$ & 0.37 & 0.18 & 0.15 & 0.18 \\
\hline $\mathrm{Ca}^{2+}\left(\mathrm{cmol}_{\mathrm{c}} / \mathrm{dm}^{3}\right)(0.00-0.05 \mathrm{~m})$ & 0.60 & 0.87 & 0.60 & 0.84 \\
\hline $\mathrm{Ca}^{2+}\left(\mathrm{cmol}_{\mathrm{c}} / \mathrm{dm}^{3}\right)(0.05-0.10 \mathrm{~m})$ & 0.67 & 0.51 & 0.55 & 0.69 \\
\hline $\mathrm{Ca}^{2+}\left(\mathrm{cmol}_{\mathrm{c}} / \mathrm{dm}^{3}\right)(0.10-0.20 \mathrm{~m})$ & 0.38 & 0.56 & 0.58 & 0.62 \\
\hline $\mathrm{Mg}^{2+}\left(\mathrm{cmol}_{\mathrm{c}} / \mathrm{dm}^{3}\right)(0.00-0.05 \mathrm{~m})$ & 0.44 & 0.26 & 0.33 & 0.34 \\
\hline $\mathrm{Mg}^{2+}\left(\mathrm{cmol}_{\mathrm{c}} / \mathrm{dm}^{3}\right)(0.05-0.10 \mathrm{~m})$ & 0.38 & 0.53 & 0.46 & 0.27 \\
\hline $\mathrm{Mg}^{2+}\left(\mathrm{cmol}_{\mathrm{c}} / \mathrm{dm}^{3}\right)(0.10-0.20 \mathrm{~m})$ & 0.25 & 0.79 & 0.28 & 0.35 \\
\hline $\mathrm{K}^{+}\left(\mathrm{cmol}_{\mathrm{c}} / \mathrm{dm}^{3}\right)(0.00-0.05 \mathrm{~m})$ & 0.29 & -0.28 & 0.42 & 0.25 \\
\hline $\mathrm{K}^{+}\left(\mathrm{cmol}_{\mathrm{c}} / \mathrm{dm}^{3}\right)(0.05-0.10 \mathrm{~m})$ & 0.22 & 0.23 & 0.56 & 0.31 \\
\hline $\mathrm{K}^{+}\left(\mathrm{cmol}_{\mathrm{c}} / \mathrm{dm}^{3}\right)(0.10-0.20 \mathrm{~m})$ & 0.32 & 0.15 & 0.30 & 0.21 \\
\hline $\mathrm{P}\left(\mathrm{mg} / \mathrm{dm}^{3}\right)(0.00-0.05 \mathrm{~m})$ & 0.03 & -0.22 & 0.29 & 0.16 \\
\hline $\mathrm{P}\left(\mathrm{mg} / \mathrm{dm}^{3}\right)(0.05-0.10 \mathrm{~m})$ & -0.05 & -0.21 & -0.09 & 0.40 \\
\hline $\mathrm{P}\left(\mathrm{mg} / \mathrm{dm}^{3}\right)(0.10-0.20 \mathrm{~m})$ & 0.14 & -0.05 & -0.21 & 0.33 \\
\hline $\mathrm{Al}^{3+}\left(\mathrm{cmol}_{\mathrm{c}} / \mathrm{dm}^{3}\right)(0.00-0.05 \mathrm{~m})$ & -0.50 & -0.66 & -0.38 & 0.34 \\
\hline $\mathrm{Al}^{3+}\left(\mathrm{cmol}_{c} / \mathrm{dm}^{3}\right)(0.05-0.10 \mathrm{~m})$ & -0.50 & -0.70 & -0.48 & -0.70 \\
\hline $\mathrm{Al}^{3+}\left(\mathrm{cmol}_{\mathrm{c}} / \mathrm{dm}^{3}\right)(0.10-0.20 \mathrm{~m})$ & -0.28 & -0.36 & -0.40 & -0.45 \\
\hline
\end{tabular}

(1) $\mathrm{pH}\left(\mathrm{CaCl}_{2}\right)$ : $\mathrm{pH}$ in $0.01 \mathrm{~mol} \mathrm{~L}^{-1} \mathrm{CaCl}_{2}$ solution; SOM: soil organic matter, extracted by Walkley-Black method; $\mathrm{Ca}^{2+}, \mathrm{Mg}^{2+}, \mathrm{Al}^{3+}$ : extracted by $1 \mathrm{~mol} \mathrm{~L}^{-1} \mathrm{KCl}$ solution; $\mathrm{K}$ and P: extracted by Mehlich-1. Non-directional $t$-test of the module of the Pearson correlation coefficient $|r|$ for $\mathrm{n}=16$ : $\mathrm{p}<0.05$ if $|r|>0.49$.

was a corresponding increase in $\mathrm{pH}$, according to the model proposed by Miyazawa et al. (2000): $\left[\mathrm{R}-\mathrm{COOM}+\mathrm{H}_{2} \mathrm{O} \rightarrow \mathrm{R}-\mathrm{COOH}+\mathrm{OH}+\mathrm{M}\right.$, where $\mathrm{M}=\mathrm{K}, \mathrm{Ca}$, and $\mathrm{Mg}]$. Hence, in the 0.05-0.10 m layer, $\mathrm{pH}$ did not sufficiently increase as a function of increasing rates of lime application to differentiate this variable in the plots that received Brachiaria. There was, therefore, a measurable effect of lime rates only in the plots without Brachiaria.

There was no impact from liming in the 0.10-0.20 m layer (Table 1), given the slow speed at which correction of $\mathrm{pH}$ occurs at depth. This is consistent with the conclusions of Raij (2011) and Miyazawa et al. (2000). In other words, the effect of chemical correction on soil acidity initially tends to be confined to the site of application and only very slowly reaches the deeper layers.

The difficulty in correcting the subsoil when there is no plowing of the topsoil may be a consequence of the fact that carbonate and bicarbonate ions resulting from the dissociation of lime are short-lived before reacting with soil-acidity components (Miyazawa et al., 2000; Tiritan, 2001). This difficulty was attributed to the absence of lime incorporation
(Cassol, 2003), which would decrease the surface contact area between soil particles and this corrective measure, delaying the effects of liming and restricting the reactions to the surface layers of the soil.

It may be possible to effectively correct subsurface acidity from the effect of lime placed on the soil surface, but this can only occur when the $\mathrm{pH}$ of the soil solution reaches values greater than 5.0 (Quaggio, 2000) and the $\mathrm{HCO}_{3}$ species is present as a stable form in the solution. Under these conditions, $\mathrm{HCO}_{3}$, a product of the reaction of lime in the soil, can migrate as a companion anion of $\mathrm{Ca}$ and $\mathrm{Mg}$ and correct the acidity of the soil, which, in this case, must have occurred mostly at the higher rates of lime application. Thus, as proposed by Souza et al. (2007), $\mathrm{HCO}_{3}$ would not be stable in the subsurface layers with lower $\mathrm{pH}$ when it could dissociate into $\mathrm{CO}_{2}+\mathrm{OH}$, increasing the $\mathrm{pH}$. This was observed in the 0.00-0.05 and 0.05-0.10 m layers due to liming, except in the 0.05-0.10 m layer in the plots with Brachiaria.

The contribution of other inorganic anions should not be ignored in this process. In the case of soil management with conventional tillage, Raij 
(2011) stated that soil turned over by plowing and harrowing, which both degrade organic matter, favors the leaching of nitrate, which transports Ca to the subsoil, thus favoring root development. It should be noted, however, that in the case of liming in the NTS, there is an expectation of slowing the effects at depth due to the lime applied on the soil surface. This "alkalinizing wave" occurs because, even if the lime is incorporated at the beginning of the NTS, conditions will not be met for degradation of organic matter as in conventional tillage. During the mineralization of organic matter, anions such as $\mathrm{NO}_{3}^{-}$and $\mathrm{SO}_{4}^{-}$are produced and can mobilize (as companion anions) large amounts of $\mathrm{Ca}$ and $\mathrm{Mg}$ (Quaggio, 2000). However, the presence of plant residues on the soil surface manipulated in the NTS is the main driver of the efficiency of liming in correcting subsurface soil acidity (Oliveira and Pavan, 1996).

At 82 days after liming, the same effect of liming on $\mathrm{pH}$ was observed in the $0.00-0.05$ and $0.05-0.10 \mathrm{~m}$ soil layers as in the 0.00-0.05 m layer in the first crop year. Likewise, in the $0.10-0.20 \mathrm{~m}$ soil layer, the same effect on $\mathrm{pH}$ occurred in the 0.05-0.10 m layer as in the first crop year (Table 1). This indicates that the dissolution and corrective effect of the lime, both on the surface and in the lower layers, clearly continued to occur in the second agricultural year, with the dissolution and corrective effect of the increase in lime occurring as a function of depth. Furthermore, these findings may indicate LMWOA action, which may have transported $\mathrm{Ca}$ and $\mathrm{Mg}$ and thus contributed to $\mathrm{pH}$ correction in the deeper layers after initiating the exchange of these cations with $\mathrm{H}$ from the soil solution, according to the model proposed by Miyazawa et al. (2000).

Nevertheless, Brachiaria had no effect on the increase in $\mathrm{pH}$ in any of the three soil layers in the crop years assessed. From the first to the second crop year, however, there was an increase in the $\mathrm{pH}$ of all the layers (Table 2), which can be attributed to the higher dissolution time of the lime.

\section{Soil organic matter (SOM)}

At the end of the first year, i.e., at 234 DAL, no effect of liming was observed in any of the treatments in the 0.00-0.05 m layer (Table 1). The expected increase in soil organic matter (SOM) resulting from the introduction of Brachiaria and consequent increase in surface straw production was probably offset by an increase in the $\mathrm{pH}$ value in this layer, which caused increased microbial activity and SOM decomposition. In addition, it should be noted that in this first crop year, the Brachiaria straw remained on the soil surface for only 50 days after its desiccation when soil sampling was performed.

Additionally, in the 0.05-0.10 and 0.10-0.20 m layers, no effect of the liming was observed (Table 1), possibly for the same reason. There was, however, an effect of Brachiaria in decreasing the content of SOM in the 0.05-0.10 and 0.10-0.20 m layers. A decreasing trend was also observed in the 0.00-0.05 m layer, which may indicate a greater effect of LMWOAs which were mobilized from the overlying layer. Thus, the effect of the organic binders was insufficient to significantly increase the $\mathrm{pH}$, although it was sufficient to lead to a decrease in the SOM content (Table 2).

At the end of the second year (582 DAL), however, there was an increase in the SOM content in the 0.00-0.05 m layer $(p<0.10$ if the module of $r \geq 0.43$ ) and the 0.05-0.10 m layer due to the lime application rates in plots with the Brachiaria crop (Table 1). This indicates that the plots with Brachiaria produced a higher amount of SOM in these layers, corresponding to an increase in liming rate. This was expected because of the ability of Brachiaria to produce surface straw, in addition to the fact that intercropping this forage with soybean results in a higher density of plants $/ \mathrm{m}^{2}$, thereby resulting in greater production and incorporation of root biomass. The findings also indicate that Brachiaria facilitates a higher SOM deposition/decomposition rate compared with fallow areas. Over a longer observation period, this could mean a real increase in this variable to the point of surpassing its level prior to CLI adoption (Crusciol et al., 2006).

Nevertheless, this capacity for production and incorporation of SOM in soil does not imply a greater content of this variable over the first crop year. On the contrary, it indicates a lower content because the $\mathrm{pH}$ increased in all layers between the first and second crop years (Table 2), resulting in an increase in the decomposition process. The same situation is applicable to the plots without Brachiaria (between the first and second crop years), which showed a reduction in SOM. In both cases, this can be attributed to an increase in the $\mathrm{pH}$ value, enhancing these effects in the second crop year (Table 2).

The higher input of straw on the surface of the plots with Brachiaria in this crop year, however, was insufficient to promote a real increase in SOM in the 0.00-0.05 m layer compared with the plots without Brachiaria in the first crop year (Table 2) because a higher rate of decomposition was noted in the second crop year due to the observed increase in $\mathrm{pH}$ (Table 2).

Thus, for both models of agricultural production, with and without the adoption of CLI, there was a decrease in SOM in the first crop year, but in the CLI plots, this decrease was smaller due to a greater presence of organic matter on the soil surface, conditioned by the Brachiaria straw.

No increase in the SOM content was found in the 0.10-0.20 m layer as a result of liming in any of the production models tested (Table 1). This is because the SOM content is naturally reduced at depth, and 
Table 2. Effects of the agricultural production system and time after liming (days after limming - DAL) on the variables tested at the $0.00-0.05,0.05-0.10$, and $0.10-0.20 \mathrm{~m}$ layers in a Latossolo Vermelho Eutroférrico (Oxisol)

\begin{tabular}{|c|c|c|c|c|c|c|c|}
\hline Layer & $\begin{array}{c}\text { Model of } \\
\text { production }\end{array}$ & 234 DAL & 582 DAL & Mean & 234 DAL & 582 DAL & Mean \\
\hline & & & $\mathrm{pH}\left(\mathrm{CaCl}_{2}\right)$ & & & $\mathrm{SOM}\left(\mathrm{g} \mathrm{kg}^{-1}\right)$ & \\
\hline \multirow[t]{3}{*}{$0.00-0.05 \mathrm{~m}$} & -Brachiaria & $5.05 \pm 0.42 \mathrm{aA}$ & $5.28 \pm 0.61 \mathrm{bA}$ & $5.16 \pm 0.51 \mathrm{~A}$ & $33.14 \pm 3.76 \mathrm{aA}$ & $24.73 \pm 4.36 \mathrm{bA}$ & $28.94 \pm 4.06 \mathrm{~A}$ \\
\hline & +Brachiaria & $5.13 \pm 0.39 \mathrm{aA}$ & $5.34 \pm 0.39 \mathrm{bA}$ & $5.23 \pm 0.39 \mathrm{~A}$ & $31.13 \pm 4.38 \mathrm{aA}$ & $26.93 \pm 4.30 \mathrm{bA}$ & $29.03 \pm 4.34 \mathrm{~A}$ \\
\hline & Mean & $5.09 \pm 0.40 \mathrm{~A}$ & $5.31 \pm 0.50 \mathrm{~b}$ & & $32.13 \pm 4.07 \mathrm{a}$ & $25.83 \pm 4.33 \mathrm{~b}$ & \\
\hline \multirow[t]{3}{*}{$0.05-0.10 \mathrm{~m}$} & -Brachiaria & $4.39 \pm 0.26 \mathrm{aA}$ & $4.76 \pm 0.50 \mathrm{bA}$ & $4.58 \pm 0.38 \mathrm{~A}$ & $25.92 \pm 1.98 \mathrm{aA}$ & $19.46 \pm 3.83 \mathrm{bA}$ & $22.69 \pm 2.90 \mathrm{~A}$ \\
\hline & +Brachiaria & $4.52 \pm 0.26 \mathrm{aA}$ & $4.83 \pm 0.39 \mathrm{bA}$ & $4.68 \pm 0.32 \mathrm{~A}$ & $22.24 \pm 2.19 \mathrm{aB}$ & $21.04 \pm 3.30 \mathrm{bA}$ & $21.64 \pm 2.74 \mathrm{~A}$ \\
\hline & Mean & $4.46 \pm 0.26 \mathrm{~A}$ & $4.79 \pm 0.44 \mathrm{~B}$ & & $24.08 \pm 2.08 \mathrm{a}$ & $20.25 \pm 3.56 \mathrm{~b}$ & \\
\hline \multirow[t]{4}{*}{$0.10-0.20 \mathrm{~m}$} & -Brachiaria & $4.38 \pm 0.19 \mathrm{aA}$ & $4.54 \pm 0.24 \mathrm{bA}$ & $4.46 \pm 0.21 \mathrm{~A}$ & $22.99 \pm 1.19 \mathrm{aA}$ & $15.17 \pm 2.80 \mathrm{bA}$ & $19.08 \pm 1.99 \mathrm{~A}$ \\
\hline & +Brachiaria & $4.41 \pm 0.20 \mathrm{aA}$ & $4.58 \pm 0.21 \mathrm{bA}$ & $4.49 \pm 0.20 \mathrm{~A}$ & $17.36 \pm 2.37 \mathrm{aB}$ & $15.51 \pm 2.55 \mathrm{bA}$ & $16.43 \pm 2.46 \mathrm{~B}$ \\
\hline & Mean & $4.40 \pm 0.19 \mathrm{a}$ & $4.56 \pm 0.22 \mathrm{~b}$ & & $20.18 \pm 1.78 \mathrm{a}$ & $15.34 \pm 2.67 \mathrm{~b}$ & \\
\hline & & \multicolumn{3}{|c|}{$\mathrm{Ca}^{2+}\left(\mathrm{cmol}_{\mathrm{c}} / \mathrm{dm}^{3}\right)$} & \multicolumn{3}{|c|}{$\mathrm{Mg}^{2+}\left(\mathrm{cmol}_{\mathrm{c}} / \mathrm{dm}^{3}\right)$} \\
\hline \multirow[t]{3}{*}{$0.00-0.05 \mathrm{~m}$} & -Brachiaria & $6.83 \pm 1.51 \mathrm{aA}$ & $6.49 \pm 2.13 \mathrm{aA}$ & $6.66 \pm 1.82 \mathrm{~A}$ & $2.02 \pm 0.32 \mathrm{aA}$ & $2.28 \pm 0.41 \mathrm{bA}$ & $2.33 \pm 0.38 \mathrm{~B}$ \\
\hline & +Brachiaria & $6.15 \pm 1.14 \mathrm{aA}$ & $6.58 \pm 1.62 \mathrm{aA}$ & $6.36 \pm 1.38 \mathrm{~A}$ & $2.41 \pm 0.43 \mathrm{aB}$ & $2.24 \pm 0.34 \mathrm{aA}$ & \\
\hline & Mean & $6.49 \pm 1.32 \mathrm{a}$ & $6.53 \pm 1.87 \mathrm{a}$ & & $2.22 \pm 0.37 \mathrm{a}$ & $2.26 \pm 0.37 \mathrm{a}$ & $1.84 \pm 0.37 \mathrm{~A}$ \\
\hline \multirow[t]{3}{*}{$0.05-0.10 \mathrm{~m}$} & -Brachiaria & $4.78 \pm 1.02 \mathrm{aA}$ & $5.17 \pm 1.53 \mathrm{aA}$ & $4.97 \pm 1.27 \mathrm{~A}$ & $1.76 \pm 0.38 \mathrm{aA}$ & $1.91 \pm 0.36 \mathrm{aA}$ & $1.94 \pm 0.36 \mathrm{~A}$ \\
\hline & +Brachiaria & $4.55 \pm 0.76 \mathrm{aA}$ & $5.09 \pm 1.01 \mathrm{bA}$ & $4.82 \pm 0.88 \mathrm{~A}$ & $1.89 \pm 0.35 \mathrm{aA}$ & $1.98 \pm 0.37 \mathrm{aA}$ & \\
\hline & Mean & $4.66 \pm 0.89 \mathrm{a}$ & $5.13 \pm 1.27 \mathrm{~b}$ & & $1.83 \pm 0.36 \mathrm{a}$ & $1.95 \pm 0.36 \mathrm{~b}$ & $1.71 \pm 0.21 \mathrm{~A}$ \\
\hline \multirow[t]{4}{*}{$0.10-0.20 \mathrm{~m}$} & -Brachiaria & $4.40 \pm 0.72 \mathrm{aA}$ & $4.58 \pm 0.68 \mathrm{aA}$ & $4.49 \pm 0.70 \mathrm{~A}$ & $1.71 \pm 0.12 \mathrm{aA}$ & $1.76 \pm 0.30 \mathrm{aA}$ & $1.75 \pm 0.30 \mathrm{~A}$ \\
\hline & +Brachiaria & $4.22 \pm 0.53 \mathrm{aA}$ & $4.71 \pm 0.79 \mathrm{bA}$ & $4.46 \pm 0.66 \mathrm{~A}$ & $1.75 \pm 0.29 \mathrm{aA}$ & $1.83 \pm 0.31 \mathrm{aA}$ & \\
\hline & Mean & $4.31 \pm 0.62 \mathrm{a}$ & $4.64 \pm 0.73 \mathrm{~b}$ & $2.15 \pm 0.36 \mathrm{~A}$ & $1.73 \pm 0.20 \mathrm{a}$ & $1.79 \pm 0.30 \mathrm{a}$ & \\
\hline & & & $\mathrm{K}^{+}\left(\mathrm{cmol}_{\mathrm{c}} / \mathrm{dm}^{3}\right)$ & & & $\mathrm{P}\left(\mathrm{mg} / \mathrm{dm}^{3}\right)$ & \\
\hline \multirow[t]{3}{*}{$0.00-0.05 \mathrm{~m}$} & -Brachiaria & $0.66 \pm 0.11 \mathrm{aA}$ & $0.68 \pm 0.22 \mathrm{aA}$ & $0.67 \pm 0.16 \mathrm{~A}$ & $41.46 \pm 6.50 \mathrm{aA}$ & $31.51 \pm 11.54 \mathrm{bA}$ & $36.49 \pm 9.02 \mathrm{~A}$ \\
\hline & +Brachiaria & $1.07 \pm 0.60 \mathrm{aB}$ & $0.95 \pm 0.44 \mathrm{aB}$ & $1.01 \pm 0.52 \mathrm{~B}$ & $40.44 \pm 10.21 \mathrm{aA}$ & $23.58 \pm 6.81 \mathrm{bB}$ & $32.01 \pm 8.51 \mathrm{~A}$ \\
\hline & Mean & $0.87 \pm 0.35 \mathrm{a}$ & $0.82 \pm 0.33 \mathrm{a}$ & & $40.95 \pm 8.35 \mathrm{~b}$ & $27.55 \pm 9.17 \mathrm{~b}$ & \\
\hline \multirow[t]{3}{*}{$0.05-0.10 \mathrm{~m}$} & -Brachiaria & $0.39 \pm 0.11 \mathrm{aA}$ & $0.44 \pm 0.15 \mathrm{bA}$ & $0.42 \pm 0.13 \mathrm{~A}$ & $\begin{array}{c}38.95 \pm 9.98 \\
\text { aA }\end{array}$ & $\begin{array}{c}26.14 \pm 14.36 \\
\text { bA }\end{array}$ & $\begin{array}{c}32.54 \pm 12.17 \\
\mathrm{~A}\end{array}$ \\
\hline & + Brachiaria & $0.43 \pm 0.23 \mathrm{aA}$ & $0.60 \pm 0.27 \mathrm{bB}$ & $0.51 \pm 0.25 \mathrm{~B}$ & $\begin{array}{c}39.17 \pm 19.04 \\
\mathrm{aA}\end{array}$ & $\begin{array}{c}21.02 \pm 9.75 \\
\mathrm{bA}\end{array}$ & $\begin{array}{c}30.09 \pm 14.39 \\
\mathrm{~A}\end{array}$ \\
\hline & Mean & $0.41 \pm 0.17 \mathrm{a}$ & $0.52 \pm 0.21 \mathrm{~b}$ & & $39.06 \pm 14.51 \mathrm{~b}$ & $23.58 \pm 12.05 \mathrm{~b}$ & \\
\hline \multirow[t]{4}{*}{$0.10-0.20 \mathrm{~m}$} & -Brachiaria & $0.32 \pm 0.09 \mathrm{aA}$ & $0.30 \pm 0.16 \mathrm{aA}$ & $0.32 \pm 0.12 \mathrm{~A}$ & $30.58 \pm 9.50 \mathrm{aA}$ & $14.98 \pm 4.85 \mathrm{bA}$ & $22.78 \pm 7.17 \mathrm{~A}$ \\
\hline & +Brachiaria & $0.30 \pm 0.16 \mathrm{aA}$ & $0.32 \pm 0.11 \mathrm{aA}$ & $0.32 \pm 0.13 \mathrm{~A}$ & $35.80 \pm 18.39 \mathrm{aA}$ & $17.63 \pm 6.31 \mathrm{bA}$ & $26.71 \pm 12.35 \mathrm{~A}$ \\
\hline & Mean & $0.31 \pm 0.12 \mathrm{a}$ & $0.34 \pm 0.13 \mathrm{a}$ & & $33.19 \pm 13.94 \mathrm{~b}$ & $16.30 \pm 5.58 \mathrm{~b}$ & \\
\hline & & & $\mathrm{Al}^{3+}\left(\mathrm{cmol}_{\mathrm{c}} / \mathrm{dm}^{3}\right)$ & & & & \\
\hline \multirow[t]{3}{*}{$0.00-0.05 \mathrm{~m}$} & -Brachiaria & $0.07 \mathrm{aA}$ & $0.07 \mathrm{aA}$ & $0.07 \mathrm{~A}$ & & & \\
\hline & +Brachiaria & $0.03 \mathrm{aA}$ & $0.02 \mathrm{aA}$ & $0.02 \mathrm{~B}$ & & & \\
\hline & Mean & $0.05 \mathrm{a}$ & $0.04 \mathrm{a}$ & & & & \\
\hline \multirow[t]{3}{*}{$0.05-0.10 \mathrm{~m}$} & -Brachiaria & $0.26 \mathrm{aA}$ & $0.20 \mathrm{aA}$ & $0.23 \mathrm{~A}$ & & & \\
\hline & +Brachiaria & $0.33 \mathrm{aA}$ & $0.11 \mathrm{bA}$ & $0.22 \mathrm{~A}$ & & & \\
\hline & Mean & $0.29 \mathrm{a}$ & $0.16 \mathrm{~b}$ & & & & \\
\hline \multirow[t]{3}{*}{$0.10-0.20 \mathrm{~m}$} & -Brachiaria & $0.29 \mathrm{aA}$ & $0.28 \mathrm{aA}$ & $0.28 \mathrm{~A}$ & & & \\
\hline & +Brachiaria & $0.44 \mathrm{aB}$ & $0.22 \mathrm{bA}$ & $0.33 \mathrm{~A}$ & & & \\
\hline & Mean & $0.37 \mathrm{a}$ & $0.25 \mathrm{~b}$ & & & & \\
\hline
\end{tabular}

Same letters (lowercase in rows or uppercase in columns) do not differ in the $t$-test $\mathrm{p} \leq 0.05$. Rows: $t$-test for paired data. Columns: $t$-test for unpaired samples with equal or different variances according to the results of the comparison for each pair of $\operatorname{samples.~} \mathrm{pH}\left(\mathrm{CaCl}_{2}\right)$ : $\mathrm{pH}$ in $0.01 \mathrm{~mol} \mathrm{~L}^{-1} \mathrm{CaCl}_{2}$ solution; SOM: soil organic matter, extracted by Walkley-Black method; $\mathrm{Ca}^{2+}, \mathrm{Mg}^{2+}, \mathrm{Al}^{3+}:$ extracted by 1 mol L ${ }^{-1} \mathrm{KCl}$ solution; $\mathrm{K}$ and P: extracted by Mehlich-1. 
the deposition of root biomass can be compensated by decomposition due to the $\mathrm{pH}$ increase seen between the first and second crop years in all layers for both production models tested (Table 2).

\section{Calcium exchangeable}

At the end of the first crop year (234 DAL), neither liming nor the Brachiaria treatment exhibited an effect on raising the content of $\mathrm{Ca}$ in the 0.00-0.05 $\mathrm{m}$ layer of any of the plots (Tables 1 and 2).

An increase in the concentration of $\mathrm{Ca}^{2+}$ with the increase in lime was expected, since greater application rates result in greater solubilization of $\mathrm{Ca}$. When this cation does not form compounds with the LMWOAs, it tends to remain in this layer due to the low mobility of $\mathrm{Ca}$ in the form of carbonate. This characteristic is caused by the absence of companion anions (Miyazawa et al., 2000), since $\mathrm{CO}_{3}$ reacts with $\mathrm{H}$ in the soil and is released into the atmosphere in the form of $\mathrm{CO}_{2}$ through the following reactions: $\mathrm{CaCO}_{3}+2 \mathrm{H} \rightarrow \mathrm{Ca}+\mathrm{H}_{2} \mathrm{CO}_{3}$ and $\mathrm{H}_{2} \mathrm{CO}_{3} \rightarrow \mathrm{H}_{2} \mathrm{O}+\mathrm{CO}_{2} \uparrow$. Another source of this tendency is the elevation in $\mathrm{pH}$ as the acidity is corrected, which causes deprotonation (dissociation of $\mathrm{H}$ ) and the appearance of free negative charges in colloids. In turn, the effective cation exchange capacity (CEC) increases, hindering the leaching of cations at depth due to greater retention in the surface (Alleoni et al., 2009).

Thus, the effects of liming at depths are fewer when the dissolution of the lime causes surface $\mathrm{pH}$ elevation, rendering $\mathrm{HCO}_{3}$ stable in the soil solution and mobilizing it (along with other inorganic anions) at depth as a companion anion associated with polyvalent cations. In the first crop year (234 DAL), this effect reached a depth of $0.10 \mathrm{~m}$ since, in the 0.05-0.10 m layer, there was also an increase in the Ca content due to liming in all of the plots (Table 1).

Potentially, with low lime application rates, and thus, less influence on net negative charge and repulsion of water-soluble organic compounds, intake of Ca could occur due to Brachiaria in the $0.05-0.10 \mathrm{~m}$ layer. This is outlined by the model presented by Miyazawa et al. (2000) as follows: $\mathrm{R}-\mathrm{COOM}+\mathrm{H} \rightarrow \mathrm{R}-\mathrm{COOH}+\mathrm{M}$, where $\mathrm{M}=\mathrm{K}$, $\mathrm{Ca}$, and $\mathrm{Mg}$. However, such intake did not occur, possibly due to compensation from the uptake of Ca in the split-plots with Brachiaria, while the other split-plots remained fallow in the first crop year.

Additionally, at $234 \mathrm{DAL}$, there was an increase in the content of $\mathrm{Ca}$ due to liming in the 0.10-0.20 m layer in only the split-plots with Brachiaria (Table 1), indicating transport of this element to depths by LMWOAs.

At the end of the second crop year (582 DAL), an increase in the content of Ca due to liming was observed for all the plots and layers, as was expected (Table 1); however, Brachiaria did not play an observable role in this increase (Table 2).
Between the first and second crop years, there was an increase in the average Ca level only in split-plots with Brachiaria in the 0.05-0.10 and 0.10-0.20 m layers. This certainly can be attributed to the action of Brachiaria in producing LMWOAs, which, over time, mobilized Ca from the surface to the subsurface, providing evidence of the mobilization power of organic binders (Table 2).

\section{Magnesium exchangeable}

In the first crop year, at 0.00-0.05 m, the presence of Brachiaria increased the variable content of $\mathrm{Mg}$ (Table 2), although there was still an uptake by this crop, which, of course, did not occur in the split-plots in fallow. The increase in the $\mathrm{Mg}$ content in this layer due to the presence of Brachiaria probably occurred because recycling promoted the deep roots of this forage, which help translocate $\mathrm{Mg}$ taken up from the subsurface to the aerial region and then release it into the ground after decomposition (Kluthcouski et al., 2004). This recycling occurs in the case of $\mathrm{Mg}$ because of its homogeneous redistribution in the plant, unlike $\mathrm{Ca}$, which is relatively immobile in the plant (Souza et al., 2007). It also follows that this inflow of $\mathrm{Mg}$ was restricted to the 0.00-0.05 m layer because this cation was retained by $\mathrm{pH}$-dependent negative charges, which may have been created through determination of the deprotonation phenomenon by the lime (Table 1). Nevertheless, this effect from liming was not observed in this layer, the split-plots in fallow, or the split-plots that received Brachiaria, possibly due to the lower content of $\mathrm{Mg}(21 \% \mathrm{MgO})$ compared to $\mathrm{Ca}(31 \% \mathrm{CaO})$ contained in dolomitic lime, in addition to the preference for uptake of $\mathrm{Ca}$ over Mg (Lepsch, 2011).

Although we observed a displacement at depth of $\mathrm{Ca}$ in the 0.05-0.10 $\mathrm{m}$ layer due to the increased effect of lime, no effect on $\mathrm{Mg}$ was observed for this layer or the 0.10-0.20 m layer (Table 2). This is probably due to two factors: the $\mathrm{HCO}_{3}$ and other inorganic anions, as well as the LMWOAs, favored transport of $\mathrm{Ca}$ over $\mathrm{Mg}$ due to the higher content of the former in lime; and there is a preference for adsorption of $\mathrm{Ca}$ over $\mathrm{Mg}$ in the exchange compound, increasing the possibility of $\mathrm{Mg}$ being lost through leaching and thus delaying its adsorption in these layers.

In the second crop year (582 DAL), there was no effect from residual doses of lime on the elevation of $\mathrm{Mg}$ content in the soil at the depth of 0.00-0.05 m (Table 1). This may be due to the decrease in $\mathrm{Mg}$ through binding to the LMWOAs and/or formation of ion pairs with $\mathrm{HCO}_{3}$ and other organic anions. Between the first and second crop years, $\mathrm{pH}$ increased regardless of the layer or agricultural production system assessed (Table 2), favoring the stability of bicarbonate and its transport as a companion anion of $\mathrm{Mg}$. The $\mathrm{pH}$ increase also promoted an increase in the net negative charge, favoring the mobilization of LMWOAs at depth. 
In the 0.05-0.10 and 0.10-0.20 m layers (Table 1), the effect of liming led to an increase in $\mathrm{Mg}$ content, demonstrating that, in fact, there was mobilization of this nutrient at depth. This increase occurred only in the plots without Brachiaria, which, in turn, confirms that $\mathrm{Mg}$ was absorbed by roots of soybean-Brachiaria in intercropping. This is primarily due to the higher density of plants $/ \mathrm{m}^{2}$ in the intercropping plots than in those with soybean alone, as well as the relatively long vegetative period of Brachiaria, which surpassed the soybean harvest, at 57 days before the start of the 2013/2014 season. Possibly, for the same reason, the Brachiaria in these layers exerted no effect (Table 2).

The $\mathrm{Mg}$ content increased between the first and second crop years only in the 0.00-0.05 m layer and in the split-plots without Brachiaria (Table 2). This increase may be attributed to an increase in the solubility of lime over time. Additionally, in the split-plots with Brachiaria, the increase in the $\mathrm{Mg}$ content was offset by increased uptake of this nutrient compared with that observed in plots in fallow.

\section{Potassium exchangeable}

At the end of the first crop year (234 DAL), there was no increase in the level of $\mathrm{K}$ from liming in the 0.00-0.05 m layer, since $\mathrm{K}$ is not part of the composition of this chemical soil amendment (Table 1). However, there was an increase in $\mathrm{K}$ in the split-plots without Brachiaria (Table 2). This can be attributed to the recycling promoted by Brachiaria, which has deep roots and a relatively long duration of vegetative development. K returns to the surface of the soil due to leaching from leaves, according to Brady and Weil (2013), and it partially remained in this layer perhaps due to the increase in $\mathrm{pH}$-dependent negative charges as a result of the lime.

The observed accumulation of exchangeable $\mathrm{K}$ in the soil surface was similar to that found by Crusciol et al. (2006), who concluded that the amount of exchangeable $\mathrm{K}$ in the soil of a maize-Brachiaria intercrop was higher than with a maize crop alone. These authors also attributed this occurrence to the fact that, in the October spring period, Brachiaria favored the recycling of $\mathrm{K}$, which accumulated in the soil surface after straw decomposition.

In part, however, $\mathrm{K}$ was mobilized to a depth of 0.05-0.10 m, which can be concluded from the unexpected increase in $\mathrm{K}$ in this layer due to liming. The fact that this increase occurred only in the split-plots with Brachiaria allows us to infer that the LMWOAs had a role in mobilizing $\mathrm{K}$ at depth (Table 1). In spite of this, there were no differences in the average content of $\mathrm{K}$ between the plots with and without Brachiaria (Table 2), possibly because of an increase in negative charges in the 0.00-0.05 m layer. In this crop year, that layer experienced the greatest rise in $\mathrm{pH}$ (Table 1 ), thus retaining more interchangeable $\mathrm{K}$ (Table 2).
In the 0.10-0.20 m layer (Tables 1 and 2), there was no effect from lime. The mechanisms of ion mobilization in the soil likely could not reach this layer or did so without impact in the first crop year, in part due to the slowness of $\mathrm{pH}$ correction at depths, as previously discussed, and in part due to the lower quantity of water reaching the deeper layers, with consequent lower intakes of organic compounds and salts.

In the second crop year (582 DAL), there was also no increase in $\mathrm{K}$ content registered in the 0.00-0.05 m layer due to liming, as expected (Table 1), since this nutrient does not occur in lime. However, there was a higher mean content of $\mathrm{K}$ in the plots with Brachiaria, revealing that the recycling of $\mathrm{K}$ continued in the second crop year. The increase in the concentration of monovalent cations on the soil surface is hampered by preferential leaching of them over polyvalent cations (Miyazawa et al., 2000). However, they stated that the maintenance of crop residues on the soil surface in the NTS and perennial crops favors the accumulation of $\mathrm{K}$ on the soil surface.

In the 0.05-0.10 and 0.10-0.20 m layers, there was no increase in $\mathrm{K}$ content after liming (Table 1). This was expected, not only because of the lack of $\mathrm{K}$ in lime, but also because the cumulative consumption of $\mathrm{K}$ was higher in the second crop year. This is due to the establishment of the soybean-Brachiaria intercrop in plots that were previously occupied only by Brachiaria and the soybean crop in the plots that were previously in fallow.

At a depth of 0.05-0.10 m, however, the presence of Brachiaria increased the content of K (Table 2). We can infer that this resulted from transport by LMWOAs originating in the overlying layer. The increase in $\mathrm{pH}$ and consequent increase in negative soil charges (Table 2) did not inhibit retention of $\mathrm{K}$ in this layer because a change in the net charge of this cation, when associated with water-soluble organic compounds, apparently did not occur, with the cation preferentially retained by soil (Franchini et al., 1999). Thus, the increase in $\mathrm{pH}$ and elevation in the soil's negative charge did not inhibit the retention of $\mathrm{K}$ transported by LMWOA up to the depth of 0.05-0.10 m. However, nothing remained to be adsorbed in the underlying 0.10-0.20 m layer.

It should also be noted that in the first crop year, $\mathrm{K}$ was not transported to the 0.05-0.10 m layer, and the presence of Brachiaria did not increase the content of this nutrient (Table 2). This was probably caused by the greater CEC in the overlying layer, which, in the first crop year, had a higher content of SOM that was reduced over time due to the increased effects of $\mathrm{pH}$ in the second crop year (Table 2). In this agricultural year, however, there was a lower content of SOM and CEC and an excess of K, which was transported by LMWOAs and trapped in the 0.05-0.10 m layer. Therefore, between the first and 
second crop years, the content of $\mathrm{K}$ increased only in the 0.05-0.10 m layer (Table 2). There was no such increase in the $0.10-0.20 \mathrm{~m}$ layer because the nutrient mobilization mechanisms acted in this layer with lower intensity, as previously discussed.

\section{Phosphorus available}

At the end of the first crop year (234 DAL), at depths of 0.00-0.05, 0.05-0.10, and 0.10-0.20 m, there was no change in the $\mathrm{P}$ content available due to liming or the presence of Brachiaria (Tables 1 and 2). This allows us to conclude that the uptake of $\mathrm{P}$ in the plots with Brachiaria was not enough to cause a decrease in the $\mathrm{P}$ content available in the first crop year.

At the end of the second crop year (582 DAL), there was no effect on $\mathrm{P}$ from the treatments (Tables 1 and 2), except in the 0.00-0.05 m layer. In this layer, the mean P content available decreased in the presence of Brachiaria. In the plots with Brachiaria intercropped with soybean, there was a much higher density of plants $/ \mathrm{m}^{2}$ compared to plots with soybeans alone and much more time to utilize the soil, given the relatively long growth cycle of this forage crop, thus favoring the uptake of $\mathrm{P}$. It is clear, therefore, that $\mathrm{P}$ fertilization should be implemented before the intercropping of grain crops and Brachiaria is established due to the greater uptake of $\mathrm{P}$ with intercropping than with grain crops alone.

Brachiaria did not play a role in decreasing the available $\mathrm{P}$ content in the $0.05-0.10$ and $0.10-0.20 \mathrm{~m}$ layers (Table 2), possibly due to a lower SOM content at depths and, therefore, a lower $\mathrm{P}$ buffer capacity (Novais et al., 2007). This prevented a decrease in this nutrient by the uptake effect of this forage crop.

Additionally, between the first and second crop years, there was a reduction in the available $\mathrm{P}$ content in all layers, regardless of the agricultural production model assessed (Table 2). This was expected because of the increase in the extraction of this nutrient and its export through the grain harvest. This reduction can also be attributed to the decrease in SOM between the first and second years, which also occurred in all layers and plots (Table 2). With less SOM, a release of adsorption sites in the oxides may have occurred, increasing the specific adsorption and reducing the content of $\mathrm{P}$ available (Novais et al., 2007).

\section{Aluminum exchangeable}

At the end of the first crop year (234 DAL), in the 0.00-0.05 and 0.05-0.10 m layers, only the split-plots without Brachiaria showed a negative correlation between the $\mathrm{Al}^{3+}$ content and lime application rate (Table 1), possibly because in the split-plots with Brachiaria, there was a decrease in the SOM content in all layers, although not significant at 0.00-0.05 $\mathrm{m}$ (Table 2). Thus, in these split-plots, there was clearly decreased formation of organometallic compounds, increasing the content of $\mathrm{Al}^{3+}$ in the soil and preventing the liming from significantly insolubilizing this element.

Liming did not decrease the content of $\mathrm{Al}^{3+}$ in any split-plot in the 0.10-0.20 m layer (Table 1) as the "alkalinizing wave", as termed by Raij (2011), operated slowly and with insignificant impacts in this layer.

At the end of the second crop year (582 DAL), at 0.00-0.05 m, a negative correlation was also observed between liming and $\mathrm{Al}$ content only in the split-plots without Brachiaria (fallow). This possibly occurred because the greater dissolution of lime over time resulted in a lower content of SOM in this layer for all split-plots. The Al content was affected, and the correlation from the first agricultural year was preserved (Tables 1 and 2).

In the 0.05-0.10 m layer, there was a negative correlation between $\mathrm{Al}$ content and lime application rate in the split-plots both with and without Brachiaria. This may be due to increased dissolution of lime over time, leading to a lower content of $\mathrm{SOM}$ and $\mathrm{Al}$ in this layer for all the split-plots. The reduction of $\mathrm{Al}^{3+}$, however, was more intense in the split-plots with Brachiaria (Table 2), which also led to a negative correlation between application rates of lime and $\mathrm{Al}^{3+}$ content.

There was no negative correlation between application rates of lime and $\mathrm{Al}^{3+}$ content in the 0.10-0.20 m layer (Table 1), although the same events were observed as in the overlying layer. This probably occurred because at depth, lime exerted slower and less pronounced effects, as the $\mathrm{pH}$ at this layer was the lowest, ranging between the average values of 4.54 and 4.58 for the split-plots without and with Brachiaria, respectively. Under such conditions, $\mathrm{Al}$ still has some solubility (Souza et al., 2007).

\section{CONCLUSIONS}

The effects from lime were extended to deeper soil layers and over time through the mobilization of ions in the soil, leading to a reduction in soil organic matter and exchangeable aluminum content and an increase in $\mathrm{pH}$, calcium, and magnesium levels.

In the first crop year, the crop-livestock integration model led to an increase in potassium and $\mathrm{Mg}$ levels and a reduction in soil organic matter. However, in the second crop year, although the level of K still increased, the decrease in soil organic matter was lower, and the $\mathrm{P}$ content was reduced.

The effects of liming at depth and improvements in the root environment from the treatments were only partially observed through changes in the chemical properties studied. 


\section{REFERENCES}

Alleoni LRF, Camargo AO, Casagrande JC, Soares MR. Química dos solos altamente intemperizados. In: Melo VF, Alleoni LRF, editores. Química e mineralogia do solo. Viçosa, MG: Sociedade Brasileira de Ciência do Solo; 2009. p.381-447.

Alvarez CA, Stape JL, Sentelhas PC, Gonçalves JLM, Spavorek G. Köppen's climate classification for Brazil. Meteorol Zeitschrift. 2013;22:711-28.

Borghi E, Crusciol CAC. Produtividade de milho, espaçamento e modalidade de consorciação com Brachiaria brizantha em sistema plantio direto. Pesq Agropec Bras. 2007;42:163-71.

Borghi E. ILP do milho consorciado com Brachiaria brizantha em SPD [tese]. Botucatu: Universidade Estadual Paulista; 2004.

Brady NC, Weil RR. Elementos da natureza e propriedades dos solos. $3^{\text {a }}$.ed. Porto Alegre: Bookman; 2013.

Cassol LC. Relações solo-planta-animal num sistema de integração lavoura-pecuária em semeadura direta com calcário na superfície [tese]. Porto Alegre: Universidade Federal do Rio Grande do Sul; 2003.

Ciotta MN, Bayer C, Ernani PR, Fontoura SWV, Wobeto C, Albuquerque JA. Manejo da calagem e os componentes da acidez de Latossolo Bruno em plantio direto. R Bras Ci Solo. 2004;28:317-26.

Claessen MEC, Barreto WO, Paula JL, Duarte MN, organizadores. Manual de métodos de análise de solo. $2^{\mathrm{a}}$.ed. Rio de Janeiro: Embrapa-CNPS; 1997.

Crusciol CAC, Borghi E, Guaragna JG. Alterações na fertilidade do solo após dois anos de integração agricultura-pecuária. In: Resumos da $27^{\text {a }}$ Reunião Brasileira de Fertilidade do Solo [CD ROM]; 2006; Bonito [BR]. Bonito: Sociedade Brasileira de Ciência do Solo; 2006.

Crusciol CAC, Soratto RP, Borghi E, Mateus GP. Integração lavoura-pecuária: benefícios das gramíneas perenes nos sistemas de produção. Inf Agron. 2009; 125:2-15.

Denardin JE, Kochhann RA, Santi A, Faganello A, Sattler A. Efeito da consorciação milho-braquiária (Brachiaria brizantha) na mitigação da compactação do solo. Passo Fundo: Embrapa-CNPT; 2008. (Boletim de Pesquisa e Desenvolvimento, 54).

Franchini JC, Debiasi H, Sacoman A, Farias JRB. Manejo do solo para redução das perdas de produtividade pela seca. Londrina, Embrapa-CNPS; 2009. (Documentos, 314).
Franchini JC, Meda AR, Cassiolato ME, Miyazawa M, Pavan MA. Potencial de extratos de resíduos vegetais na mobilização do calcário no solo por método biológico. Sci Agric. 2001;58:357-60.

Franchini JC, Miyazawa M, Pavan MA, Malavolta E. Dinâmica de íons em solo ácido lixiviado com extratos de resíduos de adubos verdes e soluções puras de ácidos orgânicos. Pesq Agropec Bras. 1999;34:2267-76.

Kluthcouski J, Aidar H, Stone LF, Cobucci T. Integração lavoura-pecuária e o manejo de plantas daninhas. Inf Agron. 2004;106:1-20.

Lepsch IF. 19 Lições de pedologia. São Paulo: Oficina de Textos; 2011

Miyazawa M, Pavan MA, Franchini JC. Neutralização da acidez do perfil do solo por resíduos vegetais. Inf Agron. 2000; 92:1-8.

Motta ACV, Melo VF. Química dos solos ácidos. In: Melo VF, Alleoni LRF, editores. Química e mineralogia do solo. Viçosa, MG: Sociedade Brasileira de Ciência do Solo; 2009. p.313-80.

Novais RF, Smyth TJ, Nunes FN. Fósforo. In: Novais RF, Alvarez V VH, Barros NF, Fontes RLF, Cantarutti RB, Neves JCL, editores. Fertilidade do solo. Viçosa, MG: Sociedade Brasileira de Ciência do Solo; 2007. p.471-550.

Oliveira, E, Pavan, M.A. The control of soil acidity in no-till system for soybean production. Soil Till Res. 1996;38:47-57.

Quaggio JA. Acidez e calagem em solos tropicais. Campinas: Instituto Agronômico de Campinas; 2000.

Raij Bvan. Melhorando o ambiente radicular em subsuperfície. Inf Agron. 2011;135:8-18.

Santos HG, Jacomine PKT, Anjos LHC, Oliveira VA, Lumbreras JF, Coelho MR, Almeida JA, Cunha TJF, Oliveira JB. Sistema brasileiro de classificação de solos. $3^{\text {a }}$.ed. Rio de Janeiro: Embrapa-CNPS; 2013.

Souza DMG, Miranda LN, Oliveira SA. Acidez do solo e sua correção. In: Novais RF, Alvarez V VH, Barros NF, Fontes RLF, Cantarutti RB, Neves JCL, editores. Fertilidade do solo. Viçosa, MG: Sociedade Brasileira de Ciência do Solo; 2007. p.205-74.

Tiritan CS. Alterações do solo e resposta do milho à calagem superficial e incorporada em região de inverno seco [tese]. Botucatu; Universidade Estadual Paulista; 2001. 